\title{
トラック運転手のNK活性および亜群とそれに関連する要因
}

\author{
許鳴*1, 三 浦 康 司*1, 長 尾 夫美子*2, \\ 武藤 孝 司*1, 奥 村康*2 \\ *1順天堂大学医学部公衆衛生学教室，*順天堂大学医学部免疫学教室
}

\section{NK Cell Activity and Subsets of Truck Drivers along with Related Factors}

\author{
Ming XU*1, Yasushi MIURA*1, Fumiko NAGAO*2, \\ Takashi MUTO*1 and Ko OKUMURA*2 \\ *I Department of Public Health, Juntendo University, School of Medicine, Tokyo \\ * Department of Immunology, Juntendo University, School of Medicine, Tokyo
}

\begin{abstract}
We investigated the immunity and the main factors that affect the immune system of 19 truck drivers as the experimental group and 27 office workers as the control group at a transit corporation in Tokyo; all subjects in both groups were examined through an assay of NK activity and NK subsets before and after work. At the same time, they were asked to complete a questionnaire on their working hours per day (WHPD) and driving hours per day (DHPD), in addition to the Health Practice Index (HPI), Self-Rating Depression Scale (SDS), Stress Tolerance Check List (STCL), and Symptom Checklist (SCL). The results obtained were as follows:

1. Before work, no difference was seen in NK activity between the experimental group and the control group, with both groups showing $E: T$ ratios 5:1 to 20:1. After work, the NK activity ( $E: T=20: 1)$ of the experimental group was significantly lower than that of the control group.

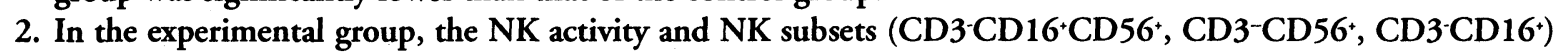
of the peripheral blood lymphocytes after work were significantly lower than before work $(p<0.05, p<0.01$, $p<0.01$ ). After more than five driving hours, the value of the $\mathrm{CD} 3{ }^{-} \mathrm{CD} 16{ }^{+} \mathrm{CD} 56^{+}$subset was significantly lower than that after fewer driving hours.

3. Correlation coefficients were calculated based on the average value of NK activity (E:T=20:1), CD3CD16 CD56' subset, and WHPD, DHPD, and HPI in the driving group. NK activity (E:T=20:1) and DHPD were found to be negatively correlated $(r=-0.28)$, as were the $\mathrm{CD} 3{ }^{-C D} 16^{\circ} \mathrm{CD} 56^{+}$subset and WHPD $(r=-0.43)$ and the CD3 CD16 ${ }^{+}$D 56 $6^{+}$subset and DHPD ( $\left.r=-0.63\right)$. On the other hand, NK activity (E:T= 20:1), the $\mathrm{CD} 3{ }^{-} \mathrm{CD} 16^{+} \mathrm{CD} 56^{+}$subset and HPI were found to be positively correlated $(\mathrm{r}=0.41$ and 0.33$)$.
\end{abstract}

Key words； NK activity（N K 活性），CD3-CD16+CD56+ subset（CD3-CD16+CD56+亜群）， Truck driver（トラック運転手），Driving hours（運転時間）， HPI（健康習慣指数）

緒言

運転が運転手に与える健康影響としては，以前よ り疲労などの自覚症状の増大が指摘されている(13)。 近年になり，運転労働により運転手のストレスが多 いことや循環器疾患, とくに心疾患による死亡の多 いことが注目されている4-9)。一方，生体の恒常性を
維持する自然免疫能であるナチュラルキラー細胞 （NK細胞）の研究の進展の中で, 不良な健康習慣は, 各種ストレスによるナチュラルキラー細胞活性（NK 活性）の抑制を通じて, NK活性の低下要因の一つと されている ${ }^{10-18)}$ 。このような背景の中で, 健康維持の ために免疫能力の低下を防ぎ, 免疫能を高めること の重要性が期待されている15-19)。しかし，今までの研

Reprint requests to: Ming Xu, Department of Public Health Juntendo University, School of Medicine, 1-1 Hongo 2-chome, Bunkyo-ku, Tokyo 113-8421, Japan 
究では, 運転労働による免疫能への影響の実態はよ くわかっていない。そこで本研究では免疫能の指標 としてトラック運転手の勤務前後のNK活性およびNK 細胞覀群（NK subsets）における変化を調べ，さらに， それらと勤務状況, 生活習慣, 自覚症状, ストレスな どとの関連性について検討を試みた。

\section{対象および方法}

\section{1. 対象と方法}

トラック運転手は運転業務の違いにより「地場」 と「路線」に分かれいる。「地場」運転は, 非長距離 で, 交通事情や目的地の変動により毎日運転路線が 違う。「路線」運転は, 高速道路で長距離運転が多く, 運転路線は安定している。今回調査対象としたトラ ック運転手は, 勤務前後に採血するため, 日勤の 「地場」トラック運転手とした。東京都内の某運送会 社の協力を得て,「地場」トラック運転手19名（以下 運転手群）と, 比較対照群として同じ運送会社に勤 務する事務職スタッフ28名（以下事務職群）を対象 とした。調査は1994年 6 月〜 7 月に行った。対象者 に勤務開始前（朝7:00～9:00）に第 1 回目の採血を行 ってから，その場で質問用紙を配布し，本人が記入 した後，その場で回収した。勤務後 (午後5:00〜 7:00) に当日の勤務時間と運転時間を質問用紙に記入して もらい, その場で回収し, 第 2 回目の採血を行った。

\section{2 . 免疫能の測定}

全対象者に 5 m の血液をへパリン採血した後，ア イス箱に入れ，1 時間で実験室に運んだ。ヒト末梢 血から Ficoll-Hypaqueで比重遠心分離して得られたリ ンパ球を分取し，RPMI 1640 medium（10\%FCS）に

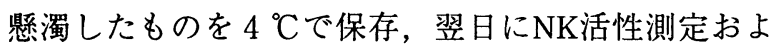
びNK subsetsの解析を行った。

（1） NK活性の測定：非放射性物質Eu-DTPAキレー トを用いた細胞障害活性測定法よりヒトNK細胞活性 を測定した ${ }^{20-22)}$ 。標的細胞（Target）としてヒト赤芽 球性白血病細胞株 K562を RPMI 1640 medium (10\%FCS) 中で継代培養し，5×106 個をBuffer A $5 \mathrm{ml}$ (50mM Hepes, $93 \mathrm{mM} \mathrm{NaCl}, 5 \mathrm{mM} \mathrm{KCl}, 2 \mathrm{mM} \mathrm{MgCl}$, pH7.4) で 2 回洗浄後, $1 m \ell$ ラベル液に懸濁し, $4{ }^{\circ} \mathrm{C}$ 20分放置した。その後, $20 \mu \ell \mathrm{CaCl}_{2}$ 添加し, 更に 5 分間 $4{ }^{\circ} \mathrm{C}$ で放置してから, Buffer B $10 \mathrm{ml}$ (50mM Hepes, $93 \mathrm{mM} \mathrm{NaCl}_{2}, 5 \mathrm{mM} \mathrm{KCl}, 2 \mathrm{mM} \mathrm{MgCl} 2,2 \mathrm{mM} \mathrm{CaCl}$, 10mM glucose, pH7.4) で洗浄した。遠心後Eu-DTPA でラベルした細胞をフィッシャーチューブに移し，

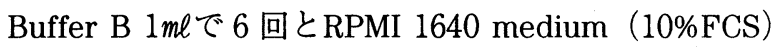
で 2 回更に洗净を行い, 細胞濃度 $1 \times 10^{5} / \mathrm{ml}$ にRPMI 1640 medium (10\%FCS) で調整した。エフェクター 細胞（Effector）としては，ヒト末梢血からFicollHypaqueで比重遠心分離して得られたリンパ球を分取 し, RPMI 1640 medium（10\%FCS）に懸濁して用い た。96穴丸底プレートにE/T比は，5:1，10:1，20：
1 でまいた。プレートを遠心後, $37^{\circ} \mathrm{C}, \mathrm{CO}_{2}$ 下で 2 時間 後, 上清液 $20 \mu \ell$ 採取し, 96穴平底プレート（Nuncイ ムノプレートI 検定付) にまき, 増強試薬（ファルマ シア制) $100 \mu \ell$ 加えて時間分解蛍光測定法（Arcus ${ }^{1232}$ Delphia fluorometer, Pharmacia）により遊離 $\mathrm{Eu}^{3+}$ 測 定した。NK活性は以下の式で計算した。

$\mathrm{NK}$ activity $=\frac{\text { Experimental } \mathrm{Eu}^{3+} \text { release }- \text { Spontaneous } \mathrm{Eu}^{3+} \text { release }}{\text { Maximum } \mathrm{Eu}^{3+} \text { release }- \text { Spontaneous } \mathrm{Eu}^{3+} \text { release }} \times 100(\%)$

（2）NK subsetsの解析：ヒト末梢血から FicollHypaqueで比重遠心分離して得られたリンパ球を $1 \times$ 106個に, 細胞表面マーカーとしてPerCP (peridininchlorophyll-a-protein) -antiCD3 (Becton Dickinson 社 提供), FITC (fluorescein isothiocyanate)-anti CD16 (Pharmingen社提供), PE (R-phycoerythrin)antiCD56（Coulter 社提供）を用いた 3 重染色し， FACScan (Becton Dickinson) 解析を行った ${ }^{2325)}$ 。解 析後末梢血リンパ球の中のCD3-CD56+ (\%), CD3$\mathrm{CD}^{+} 6^{+}(\%), \mathrm{CD} 3 \mathrm{CD} 16{ }^{+} \mathrm{CD} 56+(\%)$ 割合を算出した。 3. アンケート調査

アンケートの内容は一般項目は年齢, 身長, 体重 とした。勤務実態に関するものは, 運転歴, 月勤務 日数, 1 日勤務時間および運転時間, 荷物の積み下 ろし状況および調査当日勤務時間，運転時間とした。 健康習慣としては森本ら ${ }^{15,17,18)}$ の生活習慣調査票を用い て, 運動, 飲酒, 喫煙, 睡眠時間, 朝食, 栄養バラ ンス, 労働時間, 自覚ストレス量の 8 項目から健康 習慣指数 (Health Practice Index, HPI) を算出した。 健康習慣指数より生活習慣不良群 $(0 \sim 3$ 点), 生活 習慣中等度群 ( $4 \sim 6$ 点), 生活習慣良好群 $(7 \sim 8$ 点）に分けた。ストレス度としては, Zung抑うつ尺 度 (Self-Rating Depression Scale, SDS) の20項目 ${ }^{26,27)}$ を用い, ストレス耐性度としては桂のストレス耐性 度チェックリスト (Stress Tolerance Check List, STCL) 20項目 ${ }^{28,29)}$ を用いた。自覚症状としては日本産業衛生 学会疲労委員会が作成した「自覚症状しらべ」30項 目 ${ }^{30,31)}$ (Symptom Checklist, SCL) を採用した。

\section{4. 解析方法}

データの解析には統計プログラム・パッケージ NAP (Numerical Analysis Program) を用いた。NK活 性, NK subsets及び健康状況の項目の結果は, 平均 值士標準偏差で表し, 運転手群と事務職群の間の検 定はt-検定およびカイ 2 乗検定を用いた。勤務前後の 平均値の差の検定は, 対応のある $\mathrm{t}$-検定を用いた。 また, 免疫能とそれに影響する要因との関連性につ いてはPearson相関係数を用いた。

\section{結果}

\section{1. 一般項目および勤務実態}

今回の調査対象の47名は, 全員男性であった。運 転手群（19名）の平均年齢は35.9土9.4歳で, 平均体 
重 $68.3 \pm 9.9 \mathrm{~kg}$, 平均身長 $169.3 \pm 6.9 \mathrm{~cm}$ であった。事務 職群 (28名) の平均年齢は35.3土6.5歳で, 平均体重 $67.3 \pm 7.6 \mathrm{~kg}$, 平均身長 $170.9 \pm 5.9 \mathrm{~cm}$ であった。運転手 群と事務職群の年齢, 身長, 体重には差が見られな かった。両群の月間勤務日数, 勤務時間数には有意 差が認められなかったが, 調査当日の勤務時間は運 転手群では事務職群より有意に長かった（表 1 )。運 転手群においては, 普段 1 日の平均運転時間と当日 の運転時間の間に有意差が認められなかった。運転 歴は平均14.6土9.2年であった。運転手は全員, 運転 業務に加えて荷物の積み下ろしの作業も行っていた。

\section{NK活性およびNK subsetsの比較結果}

運転手群の勤務前のNK活性の平均值は, どのE/T比 率においても事務職群より低い傾向があったが，有 意差は認められなかった（E/T比率5：1，9.3土6.3 vs $9.5 \pm 6.3,10: 1,16.7 \pm 7.5$ vs $18.9 \pm 9.6,20: 1$, $24.6 \pm 10.2$ vs $26.1 \pm 13.0$ )。図 1 は運転手群と事務職群 の勤務前後のNK活性（E/T20:1）の平均値を示してい る。勤務後のNK活性の平均值は, 運転手群は事務職 群より有意に低かった。運転手群では, 勤務前と比 べて勤務後のNK活性の平均値は有意に低かったが, 事務職群においては勤務前後のNK活性の差は認めら なかった。

表 2 は運転手群と事務職群の勤務前後のNK subsets の変化を示している。 NK subsetsのCD3-CD16 ${ }^{+} \mathrm{CD} 56^{+}$, $\mathrm{CD} 3 \mathrm{CD}^{2} 6^{+}, \mathrm{CD} 3 \mathrm{CD} 16^{+}$の平均值は，両群それぞれ勤 務後に有意に低下した。勤務の前後いずれにおいて も運転手群のCD3-CD16+ subsetの平均值は事務職群よ り低く, $\mathrm{CD} 3 \mathrm{CD}^{-} 6^{+}, \mathrm{CD} 3 \mathrm{CD} 16^{+} \mathrm{CD}^{2} 6^{+}$subsetsの平均

Table 1 Comparison of work environments and health conditions between truck drivers and office workers.

\begin{tabular}{lcc}
\multicolumn{3}{c}{ conditions between truck drivers and office workers. } \\
\hline & $\begin{array}{c}\text { Truck drivers } \\
\text { mean } \pm \text { SD }\end{array}$ & $\begin{array}{c}\text { Office workers } \\
\text { mean } \pm \text { SD }\end{array}$ \\
\hline Work envionments & $21.0 \pm 1.3$ & $21.6 \pm 0.7$ \\
Working days per month & $9.3 \pm 1.1$ & $9.7 \pm 1.5$ \\
Working hours per day & $5.0 \pm 1.6$ & $(-)$ \\
Driving hours per day & $9.3 \pm 1.4$ & $8.4 \pm 0.6^{*}$ \\
Working hours on the survey day & $4.8 \pm 2.0$ & $(-)$ \\
Driving hours on the survey day & & \\
& & \\
Health conditions & $3.0 \pm 1.6$ & $3.2 \pm 1.6$ \\
HPI & $42.3 \pm 7.7$ & $39.3 \pm 8.5$ \\
SDS & $53.3 \pm 5.2$ & $56.2 \pm 8.3$ \\
STCL & $7.0 \pm 5.5$ & $5.4 \pm 4.6$ \\
SCL & $3.2 \pm 2.8$ & $2.7 \pm 2.1$ \\
I. & $1.9 \pm 2.0$ & $1.6 \pm 2.5$ \\
II. & $2.0 \pm 1.6$ & $1.1 \pm 1.1^{*}$ \\
\hline
\end{tabular}

*: $\mathrm{p}<0.05$ : By student's t-test

HPI : Health Practice Index

SDS : Self-Rating Depression Scale

STCL : Stress Tolerance Check List

SCL : Symptom Checklist

I . : Drowsiness and Fatigue Checklist

II. : Difficulty in Concentration Checklist

III. : Localized Physical Incongruity Checklist
值は事務職群より高かったが，いずれの場合も運転 手群と事務職の間には有意差が認められなかった。

\section{3. 健康に関するアンケートの比較結果}

表 1 は運転手群と事務職群における健康状況の比 較である。

健康習慣指数では，運転手群は事務職群より0.2低 い値を示したが，有意差が認められなかった。カイ 2 乗検定により両群における生活習慣不良群，生活 習慣中等度群, 生活習慣良好群の比率の差を検定し たが,この場合にも有意差は認められなかった。

両群の抑うつ尺度の平均得点の比較では, 運転手 群は事務職群より 3 ポイント高い值を示したが, 有 意差は認められなかった。

両群のストレス耐性度の平均得点の比較では, 運 転手群は事務職群より2.9ポイントは低い值を示した が，有意差は認められなかった。

自覚症状しらべとしては，30項目の合計点数及び 3つのカテゴリ「ねむけとだるさ」＝I，「注意集中 の困難」=II ,「局在した身体的違和感」=III として点 数を算出した。30項目の平均得点は運転手群が事務 職群より1.6ポイント高い値を示したが, 有意差は認 められなかった。I， II， III の各々の得点でも運転 手群は事務職群よりそれぞれ高い值を示した。この 中では，III得点については運転手群は事務職群より 有意に高かった。

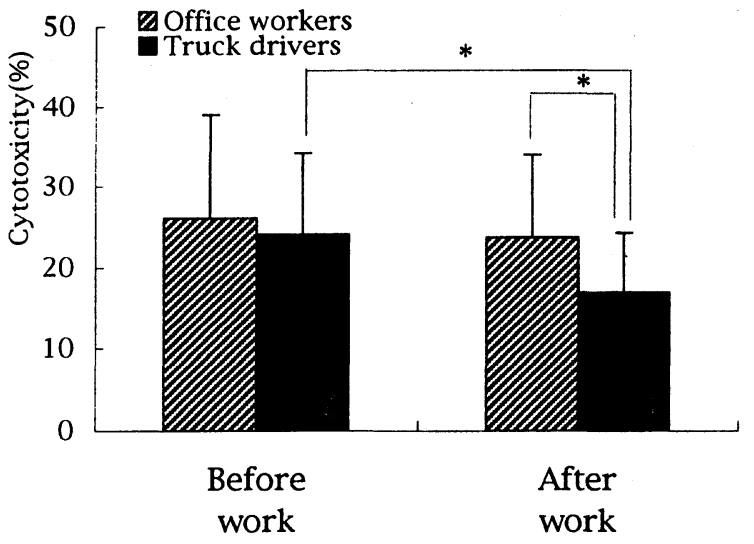

Fig. 1 Comparison of NK activity (E/T ratios:20:1) between truck drivers and office workers before and after work

*: $p<0.05$ : by Student's t-test or Paired t-test

Table 2 Comparison of NK subsets between truck drivers and office workers before and after work.

\begin{tabular}{|c|c|c|c|c|}
\hline & \multicolumn{2}{|c|}{ Truck drivers } & \multicolumn{2}{|c|}{ Office workers } \\
\hline & \multicolumn{4}{|c|}{ Before work After work Before work After work } \\
\hline CD3.CD16. CD56 & $11.9 \pm 8.9$ & $7.3 \pm 6.5^{* *}$ & $8.6 \pm 6.5$ & $5.4 \pm 3.8^{* *}$ \\
\hline $\mathrm{CD} 3 \cdot \mathrm{CD}^{+} 6^{+}$ & $12.6 \pm 9.0$ & $7.6 \pm 6.5^{* *}$ & $9.2 \pm 6.6$ & $5.8 \pm 3.9 * *$ \\
\hline $\mathrm{CD}^{-\mathrm{CD} 6^{+}}$ & $16.9 \pm 10.1$ & $11.3 \pm 7.8^{* *}$ & $17.1 \pm 8.3$ & $13.1 \pm 6.7^{*}$ \\
\hline
\end{tabular}




\section{4. 運転手の免疫能に関連する要因}

運転手の運転を始める前のNK活性（E/T比率，20： 1）およびCD3-CD16+CD56+ subsetに関連する要因につ いて, 普段 1 日の平均勤務時間および運転時間と健 康状況に関する4項目相互間の関連性を相関係数で検 討した。その結果は, 表 3 に示したように, NK活性 とHPIおよびSTCLとに有意ではないが中等度の関連 性（それぞれ $\mathrm{r}=0.41 ，-0.38$ ）がうかがわれた。運 転時間との関連には負の相関関係 $(\mathrm{r}=-0.28)$ がう かがわれたが, 勤務時間, SDS, SCLとの関連性は弱 かった。

CD3-CD16+CD56 ${ }^{+}$subsetはNK活性と同様, HPI にに 関連性（ $\mathrm{r}=0.33 ）$ がうかがわれたが, STCLとの関連 は弱かった。運転時間との間には強い負相関が示さ れた $(\mathrm{r}=-0.63)$ 。また, 勤務時間やSDSとの間には 関連性（それぞれ $\mathrm{r}=-0.43 ，-0.25 ）$ がうかがわれ た。

他方, 当日運転時間と勤務後のNK活性（E/T比率, 20 :1）およびCD3 CD16 ${ }^{+} \mathrm{CD} 56^{+}$subsetには中等度の関 連性がみられた（それぞれ $\mathrm{r}=-0.33, \mathrm{r}=-0.40$ ) が，当日勤務時間との関連性は弱かった。

運転手の普段 1 日の平均運転5 時間以上と5時間未満 のグループにより免疫能および健康状況を比較する と，表 4 に示したように長時間運転手ではCD3 CD16+CD56+ subsetが有意に低く，SCLが有意に高い

Table 3 NK activity and NK subset correlation with Working hours per day (WHPD), Driving hours per day (DHPD), Health Practice Index (HPI), Self-Rating Depression Scale (SDS), Stress Tolerance Check List (STCL), and Symptom Checklist (SCL) in the truck drivers.

\begin{tabular}{|c|c|c|c|c|c|c|c|}
\hline & NKsubset & WHPD & DHPD & HPI & SDS & STCL & SCL \\
\hline NK activity & y $0.57^{*}$ & -0.18 & -0.28 & 0.41 & -0.01 & -0.38 & 0.11 \\
\hline NK subset & & -0.43 & $-0.63^{* *}$ & 0.33 & -0.25 & -0.10 & 0.04 \\
\hline
\end{tabular}

${ }^{*}: \mathrm{p}<0.05,{ }^{* *}: \mathrm{p}<0.01$ : Correlation coefficients with statistical significance

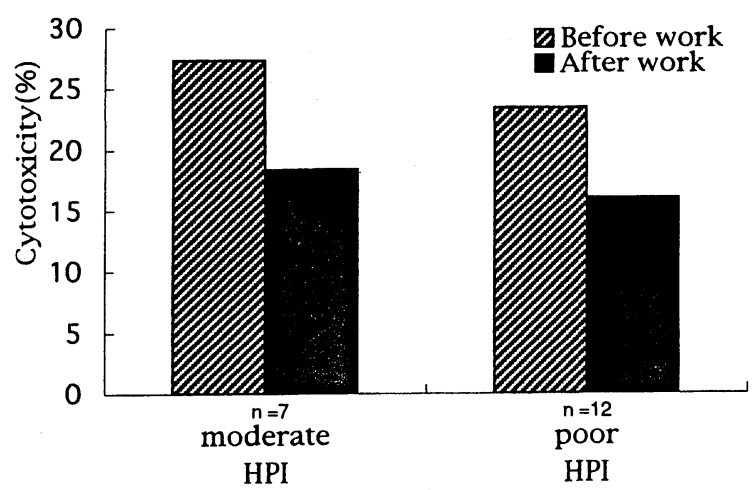

Fig. 2 Comparison of NK activity (E/T ratios: 20:1) between moderate HPI and poor HPI in the truck drivers.

moderate HPI: Health Practice Index (score 4-6) poor HPI: Health Practice Index (score 0-3)
ことが分かった。また，長時間運転手ではNK活性， HPIおよびSTCLが低く，SDSが高い傾向にあった。当 日の平均運転4.8時間以上と 4.8 時間未満のグループに より免疫能を比較すると, 長時間運転においても勤 務後のNK活性およびCD3-CD16+CD56+ subset が低い 傾向であった。

運転手の健康習慣指数により生活習慣不良群と生 活習慣中等度群の2群間で勤務前後のNK活性および $\mathrm{CD} 3-\mathrm{CD} 16+\mathrm{CD} 56^{+}$subsetを比較すると，図2，図3に示 したように両群は勤務後のNK活性およびCD3 CD16+CD56+ subsetが同じく低い傾向がみられた。

\section{考察}

トラック運転手にストレスや心疾患の多いことは

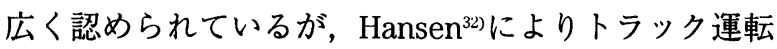
手では肺ガンのリスクが高いことが報告された。NK 細胞はウイルス, 腫瘍細胞を攻撃障害する機能をも

Table 4 Comparison of immunity and health conditions by driving hours per day and on the survey day.

\begin{tabular}{ccc}
\hline & \multicolumn{2}{c}{ Driving hours per day } \\
\cline { 2 - 3 } Before work & $<5.0 \mathrm{~h}$ & $\geqq 5.0 \mathrm{~h}$ \\
& $\mathrm{n}=9$ & $\mathrm{n}=10$ \\
\hline NK activity & $26.2 \pm 12.6$ & $23.1 \pm 7.9$ \\
NK subset & $16.4 \pm 9.9$ & $7.8 \pm 5.6^{*}$ \\
HPI & $3.4 \pm 1.0$ & $2.6 \pm 1.9$ \\
SDS & $41.2 \pm 9.4$ & $43.3 \pm 6.3$ \\
STCL & $54.9 \pm 6.3$ & $51.9 \pm 3.7$ \\
SCL & $4.2 \pm 3.6$ & $9.5 \pm 5.8^{*}$ \\
\hline & Driving hours on the survey day \\
After work & $<4.8 \mathrm{~h}$ & $\geqq 4.8 \mathrm{~h}$ \\
& $\mathrm{n}=9$ & $\mathrm{n}=10$ \\
\hline NK activity & $17.1 \pm 8.2$ & $16.3 \pm 7.9$ \\
NK subset & $9.9 \pm 8.1$ & $4.8 \pm 6.5$ \\
\hline
\end{tabular}

${ }^{*}$ : $\mathrm{p}<0.05$ : by Student's t-test

HPI : Health Practice Index

SDS : Self-Rating Depression Scale

STCL : Stress Tolerance Check List SCL : Symptom Checklist

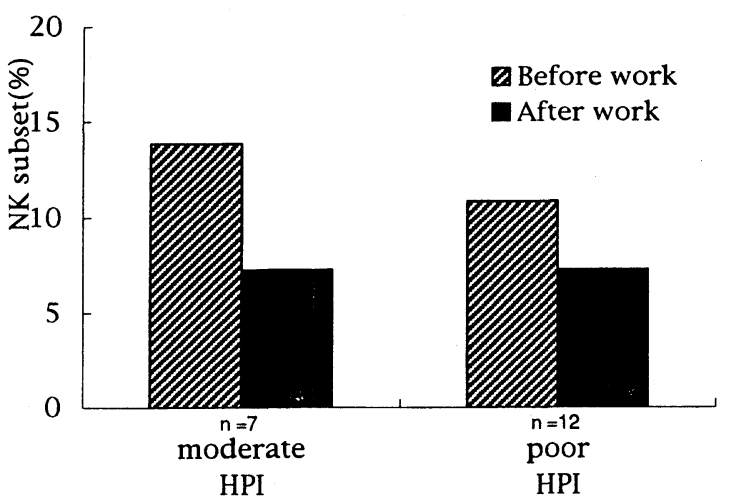

Fig. 3 Comparison of NK subset (CD3-CD16 ${ }^{+} \mathrm{CD56}^{+}$) between moderate HPI and poor HPI in the truck drivers.

moderate HPI: Health Practice Index (score 4-6) poor HPI: Health Practice Index (score 0-3) 
ち, 自然免疫系において重要な役割をもつリンパ球

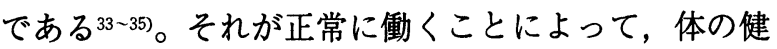
康を維持し, 病気を予防している353,38,39)。長尾ら ${ }^{36,37)}$ は 自己免疫疾患や癌患者のNK活性およびNK subsetが健 常人より有意に低いこと, また健常人集団の中でも 低NK活性および低NK subsetを有する人々が存在する と報告している。健常人集団のNK活性低下に影響す る原因としては, 年齢, 各種ストレスが多く報告 10 14,37-39)されいるが, 森本ら ${ }^{15,17,18)}$ と中治ら ${ }^{16)}$ は不良生活 習慣を報告している。

本研究より, 勤務前のNK活性には運転手群と事務 職群の差がなかったが, 運転手群にのみ勤務後にNK 活性が有意に低下することが明らかにされた。運転 労働は体力, 集中力を要求される職業で, 肉体的・ 精神的なストレスが多いことが示されている1 1290本 研究の運転手のNK活性は勤務状態の項目の中では運 転時間との関連がみられ, 長時間運転手のNK活性は 低下傾向や自覚症状が多いことが示された。黒河ら 41,42) は激しい運動負荷によりNK活性が一時的に低下す ることを報告している。本研究ではトラック運転手 自身で荷物の積み下ろしの作業をしていることより， 運転労働は重労働と考えられ, 体力を要求される運 転労働もNK活性に影響すると考えられる。本研究で 対象とした運転手群と事務職群の年齢, 勤務時間, 健康習慣指数, ストレス関連指標, 自覚症状には差 が認められず, 勤務内容以外には両群がほほ同じ条 件と考えられることから, トラック運転手のNK活性 低下の原因としては, 運転労働が関連していると思 われる。

本研究では運転労働は交感神経-副腎ホルモンにど のように影響するのかについては調査しなかった。 しかし, 先行研究では, 航空機搭乗員の唾液コルチ ゾール, 尿中カテコールアミン值は飛行後に増加する ことは明らかにされている ${ }^{43,44)}$ 。また，身体への負荷 実験によりノルアドレナリン，アドレナリンなどが 作用したエフェクター期に $\beta$ 受容体を介してNK活性 が抑制され，コルチゾールの増加がNK活性との関連 でみられている ${ }^{12,45,46)}$ 。最近の研究では, 運転手の心疾 患, 疲労, ストレスなどと交感神経-副腎ホルモンの 増加との関連が報告されている ${ }^{5,8,47}$ 。以上のことより， 運転労働が精神と身体に重い負荷を与えることより 免疫系に影響するのは, 交感神経-副腎ホルモンが関 与していると推測される。

NK活性を担うNK subsetsについては, 本研究は CD3-CD16+CD56+, CD3-CD56+, CD3-CD16+で勤務前後 に観察した。CD16+, CD56+はNK細胞に発現するレセ プタータイプの分子である ${ }^{23-25,48,49)}$ 。従来の研究では CD16+NK細胞数と NK活性の間には関連があり, CD3 CD16+CD56+ subsetはNK活性を主に担うNKsubsetであ るという報告がある35,36)。運転労働後では，3つのNK subsetsはどれも減少し，その代表であるCD3
$\mathrm{CD}^{2}{ }^{+} \mathrm{CD} 56^{+}$subsetはNK活性および運転時間との関連 が認められた。さらに，長時間運転手のCD3 $\mathrm{CD}^{2}{ }^{+} \mathrm{CD} 16^{+}$subsetが有意に低下したことから，NK subsetsの低下はNK活性の低下と同じで長時間運転が 原因と思われる。したがって，運転後のNK活性の低 下はCD3-CD 16+CD56+, CD3-CD56+, CD3-CD16+ subsetsが減少した結果としてほほ解釈可能と考えら れる。

一方，事務職群においては勤務前後 C D 3 $\mathrm{CD}^{2}{ }^{+} \mathrm{CD} 56^{+}, \mathrm{CD} 3 \mathrm{CD} 16^{+}, \mathrm{CD} 3 \mathrm{CD} 56^{+}$subsetが有意に 減少したが，NK活性の低下は認められなかった。本 研究では, 運転手群と事務職群の健康習慣指数は有 意差は見られなかったが，やや悪い傾向がみられ， ストレス耐性チェックリスト得点はやや弱い傾向が あり，ストレス度の得点や自覚症状は多い傾向があ ったが，これは，運転手の健康に関する先行研究の 結果と一致した ${ }^{1-3,5-9,50)}$ 。また, 事務職の疲労やストレ スなどは運転手より少なく，このために勤務前後の NK活性が事務職では低下しなかったと思われる。

運転時間以外に運転手の免疫能に影響する要因と みられる健康習慣指数，ストレス度，ストレス耐性 度, 自覚症状の指標の中では, NK活性及びCD3 $\mathrm{CD} 16^{+} \mathrm{CD} 56^{+}$subsetとの関連性が認められたのは健康 習慣指数のみであった。本研究では運転手群におけ る健康習慣指数と勤務前後の NK活性およびCD3 CD16+CD56 ${ }^{+}$subsetとの関連について検討したが，NK 活性およびCD3-CD16+CD56 ${ }^{+}$subsetに関して，生活習 慣中等度群と生活習慣不良群における低下のパター ンはほほ同じであった。しかし，運転手の生活習慣 不良群のNK活性およびCD3CD16 ${ }^{+} \mathrm{CD} 56^{+}$subset は勤 務前にすでに生活習慣中等度群より低かった。この 結果は健康集団を対象として生活習慣不良群のNK活 性が低下していたという森本ら ${ }^{15,17,18)}$ の研究と一致し ている。すなわち, 良好な生活習慣は運転手の免疫 能に影響する重要な要因の1つと考えられる。今後, 運転職場で健康管理の一環として, 今回得られた知 見より，運転業務を改善するとともに，好ましい健 康習慣を増やすことは, 運転手の免疫能を維持する ことにも重要な意義あるものと考えられる。

\section{結 論}

本研究の結果, 運転手群と事務職群のNK活性 （E/T20：1）は，勤務前では差が認められなかったが, 勤務後では運転手群は事務職群より低值であった。 運転手群のNK活性と末梢血リンパ球の中のCD3. $\mathrm{CD}^{2}{ }^{+} \mathrm{CD} 56^{+}$, CD3-CD56+, CD3CD16+subsetsの割合は 勤務前に比べて勤務後に有意に減少した。運転時間 が5時間以上の運転手のCD3-CD16+CD56+ subsetの割合 は短時間運転より有意に低かった。

運転手群においてはNK活性（E/T20：1）および CD3 ${ }^{-} D 16+{ }^{+} D 56+$ subset と健康習慣指数とに関連性が 
示唆され，また，運転時間とは負の相関が示唆され た。CD3 $\mathrm{CD}^{-} 6^{+} \mathrm{CD} 56^{+}$subsetと勤務時間，運転時間と の間には負の相関が示唆され，運転時間との間には かなり強い負の相関がみられた。

\section{謝 辞}

稿を終えるにあたり, 御助言頂きました順天堂大学 医学部公衆衛生学教室の福渡靖先生, 西田美佐先生, 木村康一先生, および日本赤十字社中央血液セン夕 一の屋部登志雄先生に深く感謝致します。

\section{文献}

1) 鳥越 光. 交通疲労に関する研究. 久留米医学 会雑誌 $1966 ; 29 ： 919-39$.

2) 運転労働安全委員会. 運転労働者の健康と安全 に関する調查結果. 産業医学 $1975 ; 17$ : 527-61.

3) 上田照子, 橋本美知子, 安井一清, 須永匡彦, 東田敏夫，原一郎．タクシー運転者の健康に関 するアンケート調査. 産業医学 1989 ；31：16275 .

4) 上畑鉄之丞, 阿部真雄, 千田忠男. 夕クシー・ ハイヤー・運転手の在職死亡とその原因. 日本 災害医学会会誌 $1985 ; 33: 91-7$.

5) Evans GW, Carrère $S$. Traffic congestion, perceived control, and psychophysiological stress among urban bus drivers. J Applied Psychology 1991; 76: 658-63.

6) 前原直樹.バス・トラック・タクシー運転者の 過労・ストレス状態と循環器疾患。ストレス科 学 $1995 ; 10: 38-43$.

7) Orris $P$, Hartman DH, Strauss P, Anderson RJ, Collons J Knopp C, Xu Y, Melius J. Stress among package truck drivers. Amer J Industral Med 1997; 31: 202-10.

8) Vivoli G, Bergomi M, Rovesti S, Carrozzi G, Vezzosi A. Biochemical and haemodynamic indicators of stress in truck drives. Ergonomics 1993; 36: 1089-97.

9) Armold PK, Hartley LR, Corry A, Hochstadt D, Penna F, Feyer AM. Hours of work, and perceptions of fatigue among truck drivers. Accid Anal Prev 1997; 29: 471-7.

10) Shavit Y, Lewis JM, Teaman GW, Gale RP, Liebeskind JC. Opioid peptide mediate the suppressive effect of stress on natural killer cell cytotoxicity. Science 1984; 223: 188-90.

11) Evans DL, Leserman J, Pedersen CA. Immune correlates of stress and depression. Psychopharmacol Bull 1989; 25: 319-24.

12) Levy SM, Herberman RB, Simons A, Whiteside T, Lee T, McDonald R, Beadle M. Persistently low natual killer cell activity in normal adults: immunological, hormonal and mood correlates. Nat Immun Cell Growth Regul 1989; 8: 173-86.

13) Levy SM, Herberman RB, Lee J, Whiteside T, Beadle M, Heiden L, Simons A. Persistently low natural killer cell activity, age and environmental stress as predictors of infectious morbidity. Nat Immun Cell Growth Regul 1991; 10: 289-307.

14) Sieher WJ. Modulation of human natural killer cell activity by exposure to uncontrollable stress. Brain behav Immun 1992; 6: 141-56.

15）日下幸則, 森本兼襄. ライフスタイルはナチュ ラルキラー細胞活性を変化させるか？日本衛 生学雑誌 $1992 ； 46 ： 1035-42$.

16) Nakachi K, Imai K. Environmental and physiological influences on human natural killer cell activity in relation to good health practices. Jpn J Cancer Res 1992; 83: 798-805.

17）森本兼裏，白川太朗，日下幸則，近藤 弘，ラ イフスタイルと免疫学的防御機構. Therapautic Research $1992 ; 13: 2486-92$.

18) Kusaka $Y$, Kondou H, Morimoto K. Health lifestyles are associated with higher natural killer cell activity. Preventive Medicine 1992; 21: 602-15.

19）島村忠勝. 産業保健への免疫学の応用. 公衆衛 生 $1992 ; 56: 148-51$.

20) Blomberg K, Granberg C, Hemmila I, Lovgren T. Europium-labeled target cells in an assay of natural killer cell activity. I. a novel non-radioactive method based on time-resolved fluorescence. $\mathrm{J}$ Immunol Methods 1986; 86: 225-9.

21) Blomberg $K$, Granberg $C$, Hemmila I, Lovgren T. Europium-labeled target cells in an assay of natural killer cell activity. II. a novel non-radioactive method based on time-resolved fluorescence: significance and specificity of the method. J Immunol Methods 1986; 92: 117-23.

22）長尾夫美子, 中田元巳. 非放射線物質ユーロピ ウムを用いて細胞障害試験の利点と欠点, Medical Immunology 1992; 23: 84-8.

23) 部屋登志雄, Houchins JP, McSherry C, Bach FH. NK細胞に特異的な新しいレセプター遺伝子ファ ミリー. Medical Immunology $1991 ; 21$ : 71320.

24) Moretta A, Tambussi G, Bottion C, Tipodi G, Merli A, Ciccone E, Pantaleo G, Moretta L. A novel surface antigen expressed by a subset of human CD3 $\mathrm{CD}^{-} 6^{+}$natural killer cells: role in cell activation and regulation of cytolytic function. $\mathrm{J}$ Exp Med 1990; 171: 695-714.

25) Lanier LL, Le AM, Civin CI, Loken MR, Phillips JH. The relationship of CD16 (Leu-11) and Leu-19 
(NKH-1) antigen expression of human peripheral blood NK cells and cytotoxic T lymphocytes. J Immunol 1986; 136: 4480-6.

26) Willian WK. Zung. A Self-Rating Depression Scale. Arch Gen Psychiatry 1965; 12: 63-73.

27）関口 透. メンタルヘルスと心理テスト.ここ ろの科学 $1988 ; 21: 80-7$.

28) 折津政江, 村上正人, 桂 戴作. 健常人のライ フスタイルとストレス。心身医療 $1990 ; 2$ : 89-8.

29) 折津政江, 村上正人, 桂 戴作, 野崎貞彦. ス トレス耐性度チェックリストの検討, 心身医学 $1991 ; 36: 490-6$.

30）日本産業衛生協会産業疲労研究会自覚症状調查 検討小委員会. 産業疲労の「自覚症状しらべ」 （1970）についての報告」. 労働の科学 1970 ; $25: 12-62$.

31) 武藤孝司. 疲労自覚症状調査. 保健の科学 $1991 ; 33: 686-91$.

32) Hansen ES. A follow-up study on the mortality of truck drivers. Amer J Industral Med 1993; 23: 81121.

33) Pross HL, Baines MG, Rubin P, Shragge P, Patterson M. Spontaneous human lymphocyte-mediated cytotoxicity against tumor target cells. IX. Quantitation of natural killer cell activity. J Clin Immunol 1981; 1: 51.

34) Rager-Zisman B, Bloom BR. Natural killer cells in resistance to virus infected cells, Springs seminares in Immunopathlogy 1982; 4: 397-414.

35) Whiteside TL, Herberman RB. The role of natural killer cells in human disease. Clin Immunol Immunopathol 1989; 5: 31-23.

36) Nagao F, Yabe T, Xu M, Okumura K. Phenotypical and functional analysis of natural killer cells from low NK activity individuals among healthy and patient populations. Nat Immun 1995; 14: 225-33.

37) Nagao F, Yabe T, Xu M, Yokoyama K, Saito K, Okumura K. Application of non-radioactive europium $\left(\mathrm{EU}^{3+}\right)$ release assay to a measurement of human natural killer activity of healthy and patient populations. Immunological Investigation 1996; 29: 507-18.

38) Penscow J, Mackay IR. NK and K cell activity of human blood: differences according to sex, ageand disease, Annals of the Rheumatic Disease. 1980; 39: 82-6.

39) Fernandes G, Gupta S. Natural killing and antibodydependent cytotoxicity by lymphocyte subpopulations in young and aging humans. J Clin Immunol 1981; 1: $141-8$.

40) Krishnaraj R, Blandford G. Age-associated alterations in human natural killer cell. Clinical Immunology and Immunopathology. 1987; 45: 26885.

41）黑河佳香, 新開省一, 渡部誠一郎, 渡部修一郎, 日野精二, 渡辺 孟. 運動負荷による血中免疫 担当細胞変化. 愛媛医学 $1990 ; 9: 1-6$.

42）黑河佳香, 渡部誠一郎, 新開省一, 日野精二, 渡部修一郎, 渡辺 孟. 運動の継続による免疫 能の変化. 四国公衛誌 $1990 ; 35: 19-22$.

43）垣本由紀子. ジェット輸送機による長時間飛行 が搭乗員に及ぼす影響について。医実報告 $1985 ; 26: 131-55$.

44) Tarui H, Nakamura A. Hormonal responses of pilots flying hight-performance aircraft during seven repetitive flight missions. Aviat. Space Environ. Med. 1991; 62: 1127-31.

45) Schedlowski M, Jacobs R, Stratmann G, Richter S, Hadicke A, Tewes U, Wagner TO, F, Schmidt RE. Changes of natural killer cells during acute psychological stress. J Clin Immunol 1993; 13: 11926.

46) Pedersen BK, Ullum H. NK cell response to physical activity: possible mechanisms of action. Med Sci Sports Exerc. 1994; 26:140-6

47) Theorell T, Leymann H, Jodko M, Konarski K, Norbeck HE, Eneroth P. "Person under train" incidents: medical consequences for subway drivers. Psychosom Med 1992; 54: 480-8.

48) 平櫛順仁, 土田哲雄, 西浦正芳, 東野一彌. NK 細胞の表面形質とキラ一活性. 臨床免疫 1993 ; 25 : 1103-11.

49）田村保明，斎 為民，佐藤昇志，菊地浩吉．NK 標的細胞上のNK細胞障害性制御分子. 臨床免疫 $1993 ; 25: 1134-43$.

50) 井奈波良一, 小野桂子, 鷲野嘉映, 岩田弘敏. 長距離トラック運転手のライフスタイル．公衆 衛生 $1996 ； 60$ :824-7.

（受付 1998年 2 月 3 日 受理 1998年 4 月16日） 